\title{
Research in Testing Communication Skills in Foreign Language (English) Literature Review
}

\author{
Anisa Trifoni \\ University "Aleksandër Moisiu", Durres \\ E-mail: anisatrifoni@yahoo.it
}

\section{Doi:10.5901/ajis.2012.v2n4p253}

\begin{abstract}
:
In this paper we will concentrate on three main aspects. First we will investigate on the theory of communication and its connection with other disciplines, in order to point out to what degree they have influenced the theory of communication. We will also concentrate in the way the theory of communication relates to the language and the ways the latter expresses meaning. Secondly, we will examine various theoretical contributions concerning communicative competence. Here will be included not only the views of several scholars and linguists such as, Hymes, Chomsky, Canale and Swain, Bachman etc, but also their models of communicative competence with their advantages and disadvantages. Through this analysis we will be able to understand the way in which the concept of Communicative Competence has evolved from 1970 to these days and its implications in both teaching and learning processes of foreign language. Thirdly, the focus will be on the role of Common European Framework of Reference in assessment and testing of communication skills.
\end{abstract}

Key words: communicative competence, CEF, communication skills

\section{Introduction}

By studying the etymology of the word communication it appears that it derives from the Latin verb "communicare" (commūnicāre) which originally meant to share, divide out, impart, unite, join, in other words "to make common". However, today it is used to refer to the process of exchanging information, sharing symbols and meaning, transmitting ideas, knowledge etc. The emergence of Communication as a field of research is noted especially during the second half of the $19^{\text {th }}$ century. The science of communication as we know it today was primarily influenced by two main streams: the humanities and the social sciences.

Concerning the influence of the humanities we should go back in time and mention the ancient Greek arts and rhetoric and the contribution of other disciplines such as aesthetics, hermeneutics and linguistics that were among the traditions that were developed in the early $19^{\text {th }}$ century. The second stream that influenced the field of communication emerged a century later and included experimental psychology and the social sciences. According to Abbott (2001) the system of social science disciplines that crystallized in that period included anthropology, economics, political science and sociology but not communication. What we notice here is that communication as a science emerged as a result of research and findings in various fields. At first sight, all this variety might create the idea that communication is a ragbag of concepts and theories that differ from one another. Concerning this point, Craig (1989) agrees that the terrain is confusing if we insist on looking for some kind of grand theoretical overview that brings all communication study into focus, but he also suggests that hat communication theory is a coherent field when we understand communication as a practical discipline. He identifies seven main traditions where communication theory is based, which are as follows: rhetoric, semiotics, phenomenology, cybernetics, social psychology, socio-cultural theory and critical theory (Craig, 2011). 


\section{Theoretical contributions on communication theory}

Given this variety the traditions and research areas, scholars' perceptions and definitions of communication have been numerous, and as we shall see further, have seen numerous changes over time. Some researchers present an abstract perspective on communication, others define it more specifically, other theorists that provide a rather narrow definition, and so on. So it is clear that we cannot find a definition that will bring together researchers and produce a single view on communication as a science. Following, we will consider various definitions and viewpoints expressed by well-known personalities in the field of communication.

According to Shannon and Weaver $(1949,95)$ "Communication is all of the procedures by which one mind can affect another." It is clear that this definition is too broad and general. Miller. K $(2002,5)$ argues that Weaver's definition includes virtually everything, and therefore does not help us to distinguish communication from other forms of human activity. In order to illustrate this point she brings the following example: "If one person decided to plant a flower and another person noticed it, this would count as communication." (ibid)

Another researcher, Hoben (1954) believes that "communication is the verbal exchange of a thought or idea." What is interesting in this definition has to do with the fact that here the success of the exchange of ideas or thought is considered achieved. Meanwhile, Berelson et al $(1964,254)$ does not focus on the success of communication. He provides the following definition: "Communication [is] the transmission of information, ideas, emotion, skills etc, by the use of symbols - words, pictures, figures, graphs etc. It is the act or process of transmission that is usually called communication." In this case, we understand that the information is transmitted, but not necessarily received or understood by the other person.

According to Littlejohn and Foss (2005), a variety of terms are used to define communication, such as symbols, parole, understanding, process, transmission, channel, meaning and situation. But more specifically this is found in Crystal (2003:85) who supports the idea that "Communication refers to the transmission of information (a 'message') between a source and receiver using a signalling system: in linguistic contexts, source and receiver are interpreted in human terms, the system involved is a language, and the notion of response to (or acknowledgement of) the message becomes of crucial importance. In theory, communication is said to have taken place if the information received is the same as that sent."

Another leading figure in the field of communication, Pearce. W (1989) comes up with the idea that we live in communication and not outside communication and use it for our purposes. However, King. S $(1989,1)$ presents a more social dimension of communication. She emphasizes that effective communication between people is central to personal, social and natural harmony. Understanding of oneself, family, friends and the surrounding environment requires communication. However, further on we will examine the theoretical contributions of some influential researchers in this field, since our main goal is to present the main viewpoints on communication theory.

Earlier studies on the theory of communication were concentrated on the language and the ways in which the latter expresses meaning. Among the first who contributed in this area was the French linguist Ferdinand de Saussure, with the semiotic theory in early 1900. Among, others, he suggested that the language was a system of signs where the words are used to mark objects. In the same line are Baylon et al $(2003,22)$ according to whom: "The prototype of linguistic sign is the word, but we rarely talk with separate words. The words themselves are made to be used in compound sentences, which are macro signs," It is important to emphasize here that Saussure was the first who made the distinction between language and speech. According to Saussure (1916) through the spoken or written word it is possible to use linguistic systems in real life situations.

Pierce's model, though more complex than the one presented by Saussure, bares many similarities with the latter. Cobley (1996) maintains the opinion that the main difference between them lies in the fact that Saussure's model is based only on linguistics, whereas Peirce's model apart from linguistics, is based on theories of mathematics, philosophy and logic. Despite the differences, both these scholars put forward a line of thought that considered language as a system of signs that functions according to certain rules. So, 
referring to English language (since we are studying this one), we can say that the rules take the form of the grammar of this language. On the other hand, both of them considered language as consisting of separate units, such as words, sentences, etc., which can be studied independently of each other, separated from the context.

After Saussure and Peirce, various theories were developed about the science of communication. One of them was information theory, developed by Claude Shannon and Warren Weaver in 1949 and inspired especially by systems theory and cybernetics. It plays an important role in the field of telecommunications, but concerning research on human communication, its role is limited. This is due to the fact that its primary goal is the transmission of information regardless of its content. According to Littlejohn and Foss $(2007,64)$ despite the unquestionable influence on the development of communication theory, this model has a number of shortcomings. They argued that this model, does not take into consideration the impact of contexts and environments in communication. This partial effect is observed not only in the understanding of communication in general, but also in the specific forms of communication such as: speaking, reading, writing and listening.

Another interesting but somewhat less developed branch of communication science is Pragmatics of communication. Its object of study is related to a series of problems in human communication. Unlike the theories outlined above, this theory was elaborated by a group of doctors (Paul Watzlawick, Janet Helmick Beavin, and Don Jackson), who aimed to study the effects of communication on behaviour. In a broader context, pragmatics deals with social interaction and more specifically with aspects of effective communication. Their model of communication was introduced in 1967 in the book Pragmatics of human communication. Their model was presented by means of five axioms which are as follows:

1. One cannot not communicate.

2. Every communication has a content and a relationship aspect, so that the latter determines the former and thus is a metacommunication.

3. The nature of a relationship depends on how both parties punctuate the communication sequence.

4. Human beings communicate both digitally and analogically.

5. All communication is either symmetrical or complementary.

These axioms give us a complete picture of the way communication is accomplished and through them it is clarified the role of Watzlawick and his colleagues in the field of interpersonal communication.

However, this analysis would be incomplete if we left out the contribution of the linguist Roman Jakobson. According to Lanigan. $(1991,1)$ "for most of the $20^{\text {th }}$ century Roman Jakobson's name will have been synonymous with the definition of communication as a human science." He developed a communication model that is widely used to analyze both verbal and nonverbal communication although initially he aimed only the former one. Jakobson $(1960,353)$ identified three basic factors (the addresser, the addressee and the message) and three other factors (context, contact, code). But to communicate does not mean that you simply send a message to the addressee; a common code should exist for those who take part in communication, as well as a channel through which the message is sent. Each of these factors has a different communicative function. Sorensen (1987:179) is of the opinion that the communication model introduced by Jakobson can be used in every field ranging from natural sciences to the humanities, but to be applicable it must be accompanied by further explanations."

\section{Theoretical contributions on communicative competence.}

Concerning communicative competence, Dell Hymes was first to present it as a concept, with the aim to challenge the theory of competence introduced by Chomsky. According to the latter, the linguistic theory (where he made a distinction between grammatical competence and performance) is concerned primarily with an ideal speaker-listener, in a thoroughly homogeneous linguistic community, who knows his language perfectly and is not affected by such irrelevant conditions such as memory limitations, distractions, and errors (random or characteristic) in the use of linguistic knowledge in actual performance (Chomsky, 1965: 3). 
As a matter of fact, if you carefully analyze Chomsky's linguistic theory, it is evident that his aim is to characterize the abstract abilities of speakers that allow them to produce correct sentences in their mothertongue. Focusing on linguistic competence, he claims that the consideration of social factors is completely out of the realm of linguistics.

It is here that Hymes (1972) interferes by stating that such a view of linguistic theory is inadequate and that it should be considered as part of a more general theory which includes communication and culture. Unlike Chomsky, Hymes related the concept of communicative competence not only with the theoretical aspect, but also with the practical one. As a result, his concept of communicative competence includes not only linguistic competence or knowledge of the rules of grammar but also sociolinguistic knowledge of the rules of using the language in context "without which grammatical rules will not have any value" Hymes (1972: 278). The inclusion of context has a special role because, according to Hymes, an individual is able to form grammatically correct sentences, which are completely inappropriate in a particular context. This view is strongly supported by Hedge (2000) who claims that Hymes perspective includes not only the knowledge but also the skills to use this knowledge in communication.

However, if you consider it from a broader perspective, Hymes discusses communicative ability in somewhat general terms. We notice this aspect in Cooley \& Roach (1984) according to whom, although Chomsky and Hymes gave an important contribution in relation to communicative competence, their early definitions lack detailed explanations, necessary for a theoretical concept of competence. Savignon $(1997,17)$ expresses her reserves when she states that "Hymes definition is formulated from the perspective of anthropology and not that of language teaching..." During the 80s - many were the linguists who tried to be more specific in their definitions, focusing particularly on the theory of foreign language acquisition and testing. Some of them who made valuable contributions in this field will be mentioned below.

To clarify the concept of communicative competence, Widdowson (1983) distinguished between competence and capacity. According to him, competence, i.e. communicative competence, is the knowledge of linguistic and sociolinguistic conventions, whereas with capacity he understood the ability to use knowledge as means of creating meaning in a language. Based on this distinction, it is clear that ability is not a component of competence. It remains "an active force for continuing creativity", i.e. a force for the realization of what Halliday called the "meaning potential" (Widdowson, 1983:27). By making this distinction, Widdowson was the first who between competence and performance gave more attention to performance or real language use.

Earlier Canale and Swain (1980) had worked on the definition of communicative competence in the context of second language teaching. These scholars are often cited for their view concerning the communicative nature of language. This point of view has to do with the relationship between linguistic systems and their communication values in the ability to use language for different purposes. According to them, communicative competence could be understood as a synthesis of an underlying system of knowledge and skills needed for communication. With 'Knowledge' these researchers refer to individual knowledge about language and aspects of its use whereas with 'Skills' they understand the way an individual can use knowledge in a communication situation. The model presented by these researchers initially consisted of three components: grammatical competence, sociolinguistic and strategic. In a subsequent version, Canale (1984) transferred some elements from sociolinguistic competence in a fourth component labelled discourse competence.

Generally, if we compared the models of Chomsky and Canale \& Swain we would notice two major differences. Firstly, the 'competence' of Chomsky's model is similar or equivalent to 'grammatical competence' of Canale and Swain model and secondly, all other components of the latter model are completely missing in Chomsky's definition.

In her article on communicative competence, Savignon (1983) puts the emphasis mostly in the skills. Regarding the competence-performance distinction, competence implies an internal capability, whereas performance an open manifestation of competence. According to her, the competence can be observed, developed and evaluated only through performance. One of the main contributions of Celce-Murcia et al. 
(1995) had to do with the fact that the various components of communicative competence were related to each-other and it was necessary to determine the nature of these links to better understand the structure of communicative competence.

Another interesting model is the one presented by Bachman (1990); a different structural approach on communicative competence. Bachman elaborated further on the model of linguistic ability of Canale and Swain. Instead of the term 'communication skills', the researcher introduces the term 'communicative language ability'. According to this model, the communicative language ability is defined as "consisting of both knowledge or competence and the capacity of implementing, or executing that competence in appropriate, contextualized language use" Bachman (1990:84). The scholar included the following components in communicative language ability: language competence, strategic competence and psycho-physiological mechanisms.

Language competence consists of organizational and pragmatic competence. These are further subdivided in the following components: grammatical, textual, illocutionary and sociolinguistic competence.

The strategic competence consists of these components: assessment, planning and implementation.

The psycho-physiological mechanisms include the means and the way the ability is implemented. So, according to Bachman (1990), as cited in Llurda (2000) "we can distinguish the visual from the auditory channel and the productive from the receptive skill".

By comparing this model to that of Canale and Swain (1980), as two of the most influential models in the field of second language teaching it is evident that Bachman's linguistic ability is similar to the first three components of Canale and Swain's model. Whereas, concerning the strategic competence, it is classified separately, as we find in Canale and Swain's model. However, I am of the opinion that beyond Canale and Swain viewpoint, also based on the subdivisions of Bachman's model, the latter is closer to what teachers should aim to achieve at a foreign language class. This means that teachers need to consider many aspects when determining educational goals on one hand and how to meet them on the other. In a more general sense, it means to consider language not just as a system, but rather as a way of communication.

We should not forget to mention the perspective of Council of Europe (2001) concerning language proficiency, presented in the 'Common European Framework of Reference for Languages'. Here we find a model comprising: linguistic, sociolinguistic and pragmatic competence. Each of the above-mentioned competences incorporates knowledge, skills and know-how. For example, linguistic competence has to do with the knowledge of vocabulary, phonetics, syntax, and other categories of the language system. It refers to the knowledge and the competence of using language resources in order to form well-structured messages.

In this important document, sociolinguistic competence is related to socio-cultural parameters of using the language. "Through its sensitivity to social conventions (rules of politeness, norms governing relations between generations, sexes, classes and social groups, linguistic codification of certain fundamental rituals in the functioning of a community), the sociolinguistic component strictly affects all language communication between representatives of different cultures, even though participants may often be unaware of its influence." CEFR $(2001,13)$. Concerning this aspect, Leung $(2005: 122)$ observes that "there is little doubt that this socioculturally alert concept of communicative competence has had a profound influence on ELT". The last component of the model, pragmatic ability, is composed of two sub-categories: production of language functions and speech acts. In a broader sense, it "concerns the mastery of discourse, cohesion and coherence, the identification of text types and forms, irony, and parody." CEFR $(2001,13)$.

In this regard, Goullier (2007:17) points out that "success in comprehension or expression activities, through communicative tasks, is closely dependent on the development of competences, which represents the royal road to progress. The usefulness of the CEFR is that it reminds us that competences vary in nature and all contribute to pupil success".

From the foreign language perspective, in European Commission (2007), we find an interesting perception, where among other things is said that communicative competence comes as a result of the acquisition of the mother tongue, that is inextricably linked to the development of an individual's cognitive ability to interpret the world and to establish connections with others. 
The contributions mentioned above give us the idea that mastering language skills is not simply a collection of its constituent parts (morphology, syntax, vocabulary and phonology), but a mastery of linguistic forms with the aim to use them in real communication situations. Taking for granted that communication competence is the objective of foreign language teaching (Savignon 2002:6) argues that the models of communicative competence provided the basis for the emergence of communicative approach known as Communicative Language Teaching (CLT).

From the above analysis, CLT was not influenced by a single theory of learning but from a variety of ideas, models and teaching practices. According to Scollon (1994), quoted in Elwell (2011:4), "Communicative Language teaching as with all Western approaches towards education is based upon Socratic method of teaching which has dialogue at its center". This approach is characterized in every step by the perception of language as a means of communication. That constitutes the main difference from the other methods. For example, in Grammar-Translation Method or the Audio-lingual one the primary goals is on the grammatical system, though according to Little et al (2003) no doubt that both methods will claim that the aim of language learning is to communicate. With the emergence of $C L T$, the focus was no longer entirely on grammatical skills, but in the identification of other skills that are considered essential in communication through language. If you make a careful analysis, you would notice that in CLT the teacher focuses less on linguistic structures and gives more time to the use of language in class. This is due to the fact that in a real communication situation, each individual would concentrate more on the message that he/she is conveying, rather than on the grammatical accuracy of this message. This approach led to a number of innovations in the field of teaching and learning foreign languages.

\section{Theoretical contributions on the evaluation / testing communication skills}

Seen from the class context, assessment applies to all subjects. But Cooper (1984) argues that whereas hard sciences like mathematics, physics, etc. can be assessed easily because their nature does not allow for different interpretations; it has been noticed that it is very difficult to assess the use of foreign language. Assessment of foreign language is related to students' performance in general, however, we should mention that different types of tests also play a very important role. Language testing is somehow specific in nature. McNamara $(2009,607)$ would compare it to the construction of a road, and testers to engineers. According to this scholar "language testing tends to be highly technical, as tests are very complex design objects, and many skills are involved in their construction." Of course, nowadays its influence has grown significantly and we are all aware that testing has become an inseparable part of the society in which we live, since many important decisions are directly based on test results. CEFR $(2001,177)$ states that "all language tests are a form of assessment, but there are also many forms of assessment". On the importance of language tests Tsagari (2004) argues that "Language testing, generally associated with formal assessment procedures such as tests and examinations carried out at specified times and serving a variety of purposes (i.e. diagnostic, achievement, progress, etc.), is a vital component of instructional language programmes throughout the world."

But contrary to what somebody might think, language testing is not a recent phenomenon. Spolsky (1995) points out that language testing is documented at least since the Middle Ages. Further on, during World War I, with the emergence of modern scientific methods of testing, language testing was based on theories that emphasized the measurement of cognitive abilities, consequently, the focus was on the accuracy of measuring individual skills. From this perspective it is not surprising that the greatest importance was devoted to the development of the test rather than its use.

In 1961, influenced by structuralism and behaviourism in language learning, Lado (1961) introduced the model "of skills and components" in relation to second language testing. This model consisted of three elements of linguistic knowledge (phonology, vocabulary and grammar), which could be assessed separately from each other in the context of the four language skills (reading, listening, writing and speaking). Briefly speaking, according to this view, the four basic language skills were completely independent by each-other 
and thus could be tested separately. The typical form of test used in this period was the multiple choice test, applied to both receptive and productive skills. With so much focus on the knowledge of linguistic elements, it is not difficult to notice that test items were completely detached from the context and at best could show only indirectly how the students were able to use the language learned in real situations.

Council of Europe / ALTE $(2011,12)$ emphasizes that "competences appear to be discrete when we define a model of language use. However, it is very difficult to separate competencies in authentic tasks. This is because any communicative act involves many competences at the same time." They illustrate it with the example of a language learner who tries to understand someone who has stopped them on the street to ask for directions. It is natural that in addition to contextual and grammatical competence, it is also needed sociolinguistic competence to understand the context of communication as well as the illocutionary competence to interpret what the speaker wants to achieve. This means that taken in isolation, the knowledge of grammar or vocabulary is not sufficient to achieve the objectives of communication. From this simple analysis it is clear that being able to use language means much more than having knowledge or being tested about it.

These shortcomings were met to some extent by Carroll (1968), who stated that one of the main limitations of the above model had to do with testing discrete linguistic elements and that in most cases it did not reflect the use of language in real situations. In response, he introduced the integrated tests. Carroll (1968, cited in ALTE 2005, 9) explains the concept of integrated testing in this way: "Since the use of language in ordinary situations calls upon all these aspects (of language), we must further recognize that linguistic performance also involves the individual's capability of mobilizing his linguistic competence and performance abilities in an integrated way, i.e. in understanding, speaking, reading or writing in connected discourse." Examples of integrated tests are oral interviews, essays, etc.

In relation to this point, Weir (1990) emphasizes that many people probably support the view that testing a candidate's language skills is a necessary but not a sufficient element in a battery of tests, in the same way that people who appreciate a piece of music do so based on it as a whole and not just on a part. About the importance of this model, Purpura $(2008,56)$ argues that "the assessment of language by "discrete-point" tasks (i.e., those which attempt to isolate and measure the formal knowledge components separately) needed to be complemented by integrative tasks (i.e., those which assess the capacity to use several components of language knowledge at the same time-usually while performing some real-life task" This innovation enabled the spread of Carroll's model and it served as a starting point for the design of the first TOEFL test.

But regardless of the impact it had and the changes it brought this model did not escape criticism. In this regard, Baker $(1989,65)$ is of the opinion that in general, what was proposed was an appendix of test methods with discrete-points rather than their complete replacement. Morrow (1979, cited in Weir 1990) goes further when he says that neither discrete-points tests nor integrated tests enable a spontaneous production of language by the candidate, mentioning the reliance on the tester for linguistic input. He also criticized the techniques used on the grounds that they focused more on competence rather than performance, in other words, on knowledge rather than on the ability to use language. Weir (1990) argued that it was precisely this element that highlighted the need for communication ability tests.

An important turning point, as we mentioned earlier, was related to the widespread concept of communicative competence, attributed to Dell Hymes (1972). According to him, a speaker is able to formulate sentences that are grammatically correct but totally inappropriate for the context. So, at its core, communicative competence has to do not only with the ability to form correct sentences but also with the ability to use them properly in real situations. This highlighted the necessity of reflecting the sociolinguistic aspect in language tests, which was not done before.

This approach was developed further by van Ek (1975), in the so-called 'Threshold Level' published by the Council of Europe in 1975, today known as the B1 level in CEFR. In 'The Threshold Level for Modern Language Learning in Schools', Van Ek $(1976,24)$ explains that the main goal is to enable students the survival (in linguistic terms) in temporary contacts with foreign language speakers in everyday situations, either as visitors abroad or with visitors in their country, as well as to create and maintain social contacts. By 
analysing in details 'The Threshold Level', Little $(2006,174)$ adds that it " set out to define the communicative repertoire that such learners need in terms of the situations in which they must be able to understand speech and speak, the language activities they will be likely to engage in, the language functions (communicative purposes) they will have to perform, and the notions (general and specific meanings) they will need to express."

'Threshold level for modern language learning in schools' of 1976, being a promoter of communicative approach, had a comprehensive and long-term effect on educational practices and design of tests. It contributed significantly in the teaching process, moving from teaching based on the explanation of linguistic structures to learning oriented towards real situations and activities, also known as Task-based learning. In terms of testing, it was recommended an extensive use of authentic or semi-authentic materials and activities that provided a context for language use.

Furthermore, 'Threshold Level' briefly draws a distinction between tests of communicative tasks and tests of sub-skills, by supporting the first category and as Little (2006) argues "lending its support to communicative language testing without providing detailed pointers." This reflects one of the weak points of 'Threshold Level'. Another drawback was pointed out by Gerngroß (1982, cited in Meister, 2005, 40) according to whom "the model of the T-Level is useless in what concerns reading and writing exercises, because it is too much concerned with the field of tourism. Extensive reading or creative writing do not enter at all." Comprehensive reading and creative writing is not shown at all." These weak points would be reviewed and improved in subsequent editions. Despite the weaknesses, this publication of the Council of Europe is considered a very good starting point for the subsequent developments in the field of teaching, assessment and testing, in particular for CEFR.

It is based on different models of language proficiency and language use. It has a variety of aims among which is "to help partners to describe the levels of proficiency required by existing standards, tests and examinations in order to facilitate comparisons between different systems of qualifications." CEFR $(2001,21)$. To make it possible, the framework provides a system of reference consisting of six levels of mastering the language in which are based all descriptors. It consists of three basic levels $(A, B, C)$ where each one is subdivided into two other levels (A1, A2, B1, B2, C1, C2). Concerning this subdivision, Heyworth (2004: 18) is of the opinion that teachers who try to make their students aware of their progress may prefer the lower levels with the aim to increase motivation in foreign language classes. Designed to standardize language exams levels in different countries, the framework has a widespread use.

\begin{tabular}{ccccc}
$\begin{array}{c}\text { A } \\
\text { Basic User }\end{array}$ & \multicolumn{2}{c}{ B Independent User } & Proficient User \\
$\begin{array}{c}\text { A1 } \\
\text { (Breakthrough) (Waystage) }\end{array}$ & $\begin{array}{c}\text { (Threshold) } \\
\text { (Thentage) }\end{array}$ & $\begin{array}{c}\text { B2 } \\
\text { (Effective Operational }\end{array}$ & $\begin{array}{c}\text { C2 } \\
\text { (Mastery) }\end{array}$
\end{tabular}

CEFR $(2001,26)$ has also provided the subdivision of levels under various language activities in the socalled global scale, including: listening, reading, writing, participating in discussion and oral expression, which describes what users, ranging from level (A) to level (C), can do at six different levels of proficiency. For each of these divisions descriptions are made in the form of 'can do' statements. It is important to mention here that scaled descriptors are also provided for aspects of linguistic competence (lexical, grammatical, phonological, orthographic), pragmatic competence, and sociolinguistic competence.

CEFR pays special attention to the question of assessment in Chapter 9, which is dedicated to various forms of assessment such as: direct assessment, indirect assessment, objective assessment etc, which are presented in pairs. In total there are 13 pairs. Concerning this aspect Meister $(2005,95)$ argues that "it is important to understand the difference between the descriptors of communicative activities and those of aspects of proficiency, which are linked to particular competences. While the first can be used for teacher- 
assessment or self-assessment, the latter are in general more advisable for assessing learners, because they make it possible to focus not on one single performance, but on the general competence of the learner."

Focusing on productive skills, it should be noted that they are not completely different from each other; there are also similarities between them. One of the main similarities is related to the expression of meaning. As we all know, when a person writes the message in a piece of paper or when he expresses it orally, in both cases they expect the reader or listener to interpret in the same way as they do. According to Thrasher (2000) there are three main differences between writing and speaking. The first is that writing leaves behind observable data, whereas speaking does not. The second difference is that speech occurs in real time, which can not be said about writing. The third change, which is the most important for language testing, is that we can see writing as a conversation with the reader, but in fact reading is not as interactive as speech.

To test students' knowledge in the foreign language a variety of tests can be used, varying on the number of items contained in them, their order, construction etc. According to ALTE $(2005,111)$ the large number of different item types used in language testing can be categorized in various ways:

- Some are seen as objective, in that no human judgement is required in marking them, while others demand a constructed response and subjective marking methods.

- Some are based on receptive skills while others test production

- Some are text based while others are free-standing or discrete.

In conclusion we can say that Communication as a field of research emerged during the $19^{\text {th }}$ century and was primarily influenced by the humanities and the social sciences. As we mentioned, Craig (2011) identifies seven main traditions where communication theory is based: rhetoric, semiotics, phenomenology, cybernetics, social psychology, socio-cultural theory and critical theory.

Furthermore, we analysed the way the theory of communication relates to the language and the ways language expresses meaning. Various contributions including those of Saussure, Pierce, Shannon and Weaver, Roman Jakobson, Paul Watzlawick and his colleagues were mentioned along with the explanation of their perspectives on communication.

Another aspect covered was related to communicative competence, where we analyzed the characteristics of the models presented by Hymes, Chomsky, Canale and Swain, Bachman, and Council of Europe (with CEFR), pointing out both their advantages and drawbacks. The last part of this review focused on the role of Common European Framework of Reference on the assessment and testing of communication skills.

\section{References}

Abbott, A. (2001). Chaos of disciplines. Chicago: University of Chicago Press.

ALTE (2005). Materials for the guidance of test item writers (1995, updated July 2005). From: http://www.alte.org/downloads/index.php

Bachman, L.F. (1991). What does language testing have to offer? TESOL Quarterly, 25 (4): 671-704

Baker, D. (1989). Language Testing - A Critical Survey and Practical Guide. London: Edwa

Berelson, B. dhe Steiner, G. (1964). Human behavior: An inventory of scientific findings. New York: Harcourt, Brace, \& World.

Canale, M. (1984). A communicative approach to language proficiency assessment in a minority setting. në Rivera, C. (Ed.), Communicative competence approaches to language proficiency assessment: Research and application, (107-122). Clevedon: Multilingual Matters

Canale, M., dhe Swain, M. (1980). Theoretical bases of communicative approaches to second language teaching and testing. Applied Linguistics,1, 1-47.

Carroll, J.B. (1968). The psychology of language testing. në A. Davies (ed.), Language Testing Symposium: A Psycholinguistic Approach, Oxford University Press, London, 46-69.

Celce-Murcia, M., Z. Dornyei, dhe S. Thurrell.(1995). Communicative competence: A pedagogically motivated model with content specifications. Issues in Applied Linguistics 6: 5-35.

Chomsky, N. (1965): Aspects of the theory of syntax. Boston: MIT Press.

Cobley, P. (1996). The Communication Theory Reader. London: Routledge.

Cooley, R. E. \& Roach, D. A. (1984). A conceptual framework. në R. N. Bostrom (Ed.), Competence in communication: A multidisciplinary approach (pp. 11-32). Beverly Hills, CA: Sage. 
Cooper, L.P. (1984). The assessment of writing ability: a review of research. Educational testing service, Princeton: New Jork. Council of Europe (2001) The Common European framework of reference for languages: Learning, teaching, assessment, Cambridge: Cambridge University Press.

Council of Europe/ALTE. (2011). Manual for language test development and examining. For use with the CEFR. Strasbourg: Language Policy Division, available online www.coe.int/t/dg4/linguistic/ManualtLangageTest-Alte2011_EN.pdf

Craig, R. T. (2011) Mapping the Territory (Seven Traditions in the Field of Communication Theory) në Griffin, E. (Ed.) A First Look at Communication Theory. 8th edition. New York: McGraw Hill.

Craig, R. T. (1989). Communication as a Practical Discipline. in Dervin, B., Grossberg, L.,

O'Keefe, B. J., dhe Wartella. E., (eds.), Rethinking Communication, Vol. 1: Paradigm Issues, (97-122). Newbury Park, CA: Sage

Crystal, D. (2003). English as a Global Language. 2nd edition. Cambridge: Cambridge University Press

Elwell, P. (2011). The push towards communicative language teaching and its impact on the korean classroom Grin Verlak

European Commission. (2007). The key competences for lifelong learning - a European framework. Luxembourg: Office for Official Publications of the European Communities. Marrë nga http://ec.europa.eu/dgs/education_culture/publ/pdf/lllearning/keycomp_en.pdf

Goullier, F. (2007). Council of Europe Tools for Language Teaching: Common European Framework and Portfolios. English edition: Council of Europe 2007: Didier.

Hedge, T. (2000). Teaching and learning in the language classroom. Oxford: Oxford University Press.

Heyworth, F. (2004). "Why the CEF is important". In: Insights from the Common European Framework. Ed. Keith Morrow. Oxford: Oxford University Press, 12-21.

Hoben, J. B. (1954). English Communication at Colgate Re-examined. Journal of Communication 4: 77.

Hymes, D. (1972). On communicative competence. nw J.B. Pride, J.B., \& Homes, J. (eds.) Sociolinguistics (269-293). Harmondsworth: Penguin.

Këshilli i Evropës. (2001). Kuadri i perbashkët i referencës për gjuhët. Të mësuarit, të nxënët, vlerësimi. Strasburg: Këshilli i Evropës.

Lado, R. (1961), Language Testing. Longman: London.

Leung, C. (2005). Convivial communication: Recontextualizing communicative competence. International Journal of Applied Linguistics, 15 (2): 119-44.

Little, D. (2006). The Common European Framework of Reference for Languages: Contents, purpose, origin, reception and impact. Language Teaching, vol. 39, issue 3, pp. 167-190.

Littlejohn, S. \& Foss, K. (2007). Theories of Human Communication (9th Ed.). California: Wadsworth Publishing.

Littlejohn, S. \& Foss, K. (2005). Theories of human communication. ( $\left.8^{\text {th }} \mathrm{Ed}\right)$. Belmont: Thomson-Wadswoth.

Llurda, E. (2000). On competence profiency and communicative language ability. International Journal of Applied Linguistic. Vol. $10, \mathrm{Nr} .1$.

McNamara, T. (2009). Principles of testing and assessment. në Knapp, K., Seidlhofer, B., with me Widdowson, Handbook of foreign language communication and learning (491-516). Berlin: Walter de Gruyter

Meister, M. (2005). The Influence of the Work of the Council of Europe on Language Teaching in Austria.Diplomarbeit. Graz: KarlFranzens-University. Marrë nga http://www.ecml.at/documents/relresearch/meister.pdf

Miller, K. (2002). Communication Theories: Perspectives, Processes, and Contexts. Boston: McGraw-Hill.

Pearce, W. B. (1989). Communication and the human condition. Carbondale: Southern Illinois University Press.

Purpura, J.E. (2008). Assessing communicative language ability: models and their components.

në Knapp, K., Seidlhofer, B., në bashkëpunim me Widdowson, Handbook of foreign language communication and learning 7 th volume, (53-67). Berlin: Walter de Gruyter

Savignon, S. (2002). Interpreting Communicative Language Teaching. (ed.) New Haven, CT: Yale University Press

Savignon, S. (1997). Communicative Competence: Theory and Classroom practice. (2nd edition) New York: McGraw-Hill.

Savignon, S.J. (1983). Communicative competence: Theory and classroom practice. Reading, MA: Addison-Wesley

Spolsky, B. (1995). Measured Words: The Development of Objective Language Testing, Oxford University Press, Oxford.

Shannon, C. dhe Weaver, W. (1949). The mathematical theory of communication. University of Illinois Press, Urbana, IL.

Tsagari (2004). Is there life beyond language testing? An introduction to alternative language assessment. CRILE Working Papers No. 58

Thrasher, R. (2000). Lesson four: Test design and construction. L331 Language Testing. f.17.

Van Ek, J. A. (1975). The Threshold Level. Strasbourg: Council of Europe.

Van Ek, J. A. (1976). The Threshold Level for Modern Language Learning in Schools. Strasbourg (Council of Europe): Longman.

Weir, C. J. (1990). Communicative language testing. New York: Prentice Hall.

Widdowson, H. G. (1983). Learning Purpose and Language Use. Oxford: Oxford University Press. 